\title{
DEVELOPING RELIGIOUS CULTURE THROUGH INTEGRATIVE RELIGIOUS PRACTICE IN INDONESIAN STATE ISLAMIC UNIVERSITY
}

\author{
Nur Ali, Moh. Miftahusyai'an, Angga T. Prasetyo, and \\ M. Imamu $\mathcal{M}$ uttaqien \\ Universitas Islam Negeri Maulana Malik Ibrahim Malang \\ Email: nurali@uin-malang.ac.id
}

\begin{abstract}
Higher education has been accused as an environment which has less moral and religious values. The negative stereotype became more evident when some higher education institutions involved in some disputes such as brawl among students, and riots in Ramadhan and at the time of sahur. There is also State Islamic Higher Education Institution (PTKIN) among the campuses. However, some SIHEIs have constructed religious culture through Integrative Religious Practices (IRP). The paper aims at evaluating the IRP as a strategy in building campus religious culture. Interview, participant observation, and data analysis lead to the finding that IRP development was formally done in class and was informally and ceremonially applied outside the class through ma'had, students' organizations, cooperation with religious institutions, and relation across region and professions can build campus religious culture. Moreover, it also improves students' ethical behavior, empathy, and tolerant. The study suggests that religious subject in higher education and schools is developed using IRP and involves relevant units and religious organizations outside campus to improve the understanding on the socio-religious value to establish ethical, tolerant, empathy, and cooperative behavior.
\end{abstract}

el Harakah Jurnal Budaya Islam Vol. 22 No. 1 Tahun 2020 
Perguruan Tinggi telah dituduh sebagai lingkungan yang kurang mencerminkan nilai-nilai moral dan religius. Stereotip buruk ini makin diperkuat dengan keterlibatan PT dalam beberapa kericuhan seperti tawuran mahasiswa serta tawuran di bulan Ramadhan dan di waktu sahur. Di antara perguruan tinggi tersebut terdapat Perguruan Tinggi Keagamaan Islam Negeri (PTKIN). Namun ada juga PTKIN yang telah membangun budaya religius melalui Praktik Keagamaan Integratif (PKI). Tulisan ini mengevaluasi PKI sebagai strategi dalam membangun budaya religius di kampus. Wawancara, observasi partisipan, dan analisis data yang dilakukan menghasilkan temuan bahwa pengembangan PKI yang dilakukan secara formal di kelas dan diaplikasikan nonformal dan seremonial di luar kelas melalui ma'had, organisasi kemahasiswaan, kerjasama dengan lembaga keagamaan, dan pergaulan lintas daerah dan profesi dapat membangun budaya religius di kampus. Selain itu, hal itu juga dapat menumbuhkan sikap etis, empati, dan toleran di kalangan mahasiswa. Tulisan ini menyarankan agar materi keagamaan di PT dan sekolah dikembangkan dengan praktik keagamaan integratif dan melibatkan berbagai unit terkait dan organisasi keagamaan di luar kampus untuk meningkatkan pemahaman nilai-nilai sosial-keagamaan sehingga menumbuhkan perilaku agamis, toleran, empati, dan sikap saling menghargai.

Keywords: Islamic higher education; learning tradition; religious culture; religious practice.

\section{Introduction}

Higher education as a medium to generate competent future leaders is considered failed to bring skill-full graduates who can compete in the era of ASEAN community and industry revolution 4.0. Besides, many students have been involved in criminal acts and brawl. The acts destroyed learning facilities, ruined students' physical and psychological condition, and even caused the death of some students. Some social and educational figures are upset and ashamed for the acts due to the assumption that some lecturers may be involved, and it leads to egocentricity among faculties. The condition affects society trust who believes that higher education becomes place for learning and role model (Maulana, 2019; Ramadhan, 2017; Reinhard, 2019; Sulis, 2018). The campuses have responded to the bad news related to their students' attitudes. An issue reported that among the campuses, there is an Islamic higher education (Sulis, 2018). It emphasized that the dispute occurred in the Islamic university was caused by interest difference, system 
misuse, the disappointment on bureaucracy, and even worse, following the senior's habit. This condition can trigger conflict among students (Ghony, 2018). Therefore, it is essential to make lecturers and leaders more creative in carrying out curricula activities to develop an academic and religious culture on campus (Kameliah, 2017).

Several previous studies dealing with religious culture have only focused on three aspects; first, analyzing the causal factor of juvenile delinquency at school and the importance of religious value building through religious culture, Islamic ceremonies, religious activities, and role model (Hamidah, 2016; Suyitno, 2018; Syaifuddin, 2018; Maulana, 2019). Previous researcher suggested that many religious activities can build religious culture, such as accustoming students to do worship on time (Zamzami, 2015). Second, some studies focused on the prevention of juvenile delinquency by improving parental care, creating an excellent social environment, and choosing good friends (Syifaunnufush \& Diana, 2017; Andrianto, 2019). The principal, teachers, and staff should be the role model in practicing the Islamic values (Suyitno, 2018; Zamzami, 2015). Third, the impact of juvenile delinquency at school and students brawl at campuses show the parental dysfunction, the lack of educator's innovation and creation, youth identity crisis, and value shock brought by advanced information technology and social media (Ariyanik \& Suhartini, 2012; Andrianto, 2019). The three tendencies have not critically analyzed the religious culture and religious practice implementation, and also the religious learning tradition potency in building religious culture in the level of higher education.

Religious culture $(\mathrm{RC})$ is a religious atmosphere supporting all the campus members in conducting worship, ritual and religious practices, and studies on religion and science integration as well as religious literation innovatively and properly in a peaceful, calm, and serene situation. The condition is the implementation form of values taught by religion. There are three essential religious materials needed to teach in balance, namely aqidah (behavior), sharia (Islamic law), and akhlaq (morality) (Khuzaimah, 2017). They can be actualized through three aspects: physic, activities, and behavior (Setiyawati, 2015). Muhajir Effendi (in Setiyawati, 2015) offers two approaches in realizing the values to build RC. The first is a formal approach usually employed through a regular curriculum in the form of learning activities in class. However, the activities face the time limit and class regulation and it leads to the fact that religious values cannot be implemented in class optimally. The second is an informal 
approach usually done through extracurricular activities outside the class. Its implementation needs educators' creativity and innovation to optimize the function of various supporting facilities to actualize religious values in the form of religious culture.

Meanwhile, Logan \& Hartwick (2019) suggest the importance of the integrative approach in building a culture that can help developing religious literation and understanding of how religion becomes an integral part of various social science fields. Using the method, the lecturers or teachers can build a culture that can bring the campus and school to be more educated and respectful. Moreover, they can conduct studies on religion and science integration at once (Ali, 2019). Therefore, Integrative Religious Practices (IRP) and tradition as the effort to implement educational activities by using all educational components and elements become urgently needed to achieve the goal. Previous study (Ali et al., 2018) proves that a learning activity based on IRP and tradition can see the opportunities and social needs for highly competitive and ethical graduates. The integrative learning used by educational institutions generally has unique characteristics since it is based on their institution's vision and core values (Fitri et al., 2019).

IRP and tradition include all activities and atmospheres outside the class and formal learning, which can be employed by the students to achieve educational goals. Some studies on religious practices and learning tradition suggest that they refer to unsaid or implicit values, attitudes, and norms in the educational environment (Alsubaie, 2015). Meanwhile, Jerald (2006) notes that learning tradition is an inherent activity representing behavior, knowledge, and attitude indirectly, and it should be actively shown as part of social life. Hence, educators have to play positive role in the educational system at school or campus. They have to be aware and organize their part to build religious culture.

Related with the implementation of religious value in building $\mathrm{RC}$ at school and campus, some studies on religious culture and religious learning tradition found that Islamic education should emphasize on the learning experience and spiritual value implementation aspect. Therefore, both educational institutions and educators need to conduct activities and religious practices both inside and outside the class (Irsad, 2016). The importance of building RC is shown by educators, leaders, and parents' high commitment through religious activities outside the class by relating relevant elements (Hamidah, 2016). The event is usually known as the religious practice and learning tradition. They become 
solutions for educational institutions dealing with time limit in the class to achieve learning goals by optimizing the available facilities. Three approaches can be used as the basics of implementing integrative religious practice. The first is the social demand approach which is based on society needs nowadays. The plan emphasizes on the educational goals achieved through educational mission. The second one is the human resources approach, which orientates the empowerment of graduate with the job-world expectation. The concept believes that the high number of unemployment is caused by the failure of education in addressing the problems. The third one is a cost-effectiveness approach which emphasizes on the cost optimization to achieve optimal result, both quantitatively and qualitatively (Ali et al. 2018).

This study is to respond to the lack of attention on higher education potency in building RC. It has a great power to create a good shield to prevent student delinquency through IRP. Therefore, the study consists of three problems namely (1) how to build the religious culture through IRP in UIN Malang, (2) how the factor of IRP determines the success of RC building in UIN Malang, and (3) how to formulate an IRP model which can guarantee the realization of RC in UIN Malang as a reference for other general and Islamic state higher education. The questions are expected to answer the dynamics of the RC building.

Furthermore, the study is based on three arguments. First, the Islamic higher educational institutions are responsible for building RC, peace, and serene atmosphere in implementing religious values and local wisdom norms. The second is IRP implemented in educational institutions has significant impact on preventing juvenile and student delinquency. The third one is the lack of studies on IRP in the literature and conceptual models. However, it is important to consider the IRP during the building of religious culture.

\section{Method}

The authors chose Islamic higher education and its potency in building religious culture through Integrative Religious Practices (IRP) for two reasons. The first is the concern on the high number of student brawl in campus involving students and lecturers which can lead to criminal acts. The second reason is the religious and social activities outside the class, in ma'had (a Muslim student dormitory) and outside the campus have strategic roles in building religious culture, empathy, and tolerance among students. The material of the IRP can be considered as a soft strategy in implementing long term religious culture.

el Harakah Jurnal Budaya Islam Vol. 22 No. 1 Tahun 2020 
The research is based on primary data from observation and interviews. The observation itself is carried out by observing and visiting the places of religious and social activities practice in the class, in ma'had, and outside the campus to get the dynamic pictures of the religious culture-building process. The interview is done by asking the questions on the chosen material aspect, the used strategy, and activity experiences. The choosing of informants is based on the qualitative principle. The researcher decides six informants using purposive sampling with the criteria of educational background and different workplaces. They include religious lecturers, the leader of the ma'had, and students.

The primary data consisting description of religious and social activities in building RC is analyzed using stages such as data reduction, data display, and data verification. To check the data validity, the researcher employs triangulation and focus group discussion (FGD).

\section{Building Religious Culture}

Integrative Religious Practice (IRP) is one of media to shape student's character in addition to building a mindset and religious culture with a particular orientation. IRP has the potential to directly function to develop student configuration in presenting the values of spirituality and moral grandeur in social reality. Accordingly, four aspects of the IRP can be evaluated for their relevance in the creation of religious culture.

The first one, the IRP can be implemented inside and outside the classrooms. Inside the classrooms, the IRP is done by praying before the class activities begin. Some lecturers also ask students to read the Quran for the first 5-10 minutes before teaching and learning activities. This is why in every class, several Quran are placed in a bookshelf so that students can use it for reciting before learning. Outside the classrooms, IRP can be held in the form of religious ceremonial events such as Islamic-theme speech after dhuhur prayer at the at-Tarbiyah mosque using Indonesian language meanwhile at the Ulul Albab mosque, the speech is in Arabic or English because there are many foreign students. Every Thursday in the fourth week, there is a monthly agenda in the Students Center building called Khotm al-Quran held at 19.00. This activity was attended by all campus members from the leader board, lecturers, staff, and students. After finishing the Quran reading, the participants will listen to the religious and motivational speech by invited speaker-sometimes, the college invites famous figures to fill in this session. In ma'had, the IRP is 
implemented in the form of socio-religious study, religious practices, as well as religious and art rituals e.g. the practice of Hajj performance and watching inspiring movies. Students' organizations usually conduct flexible activities, for example charity for orphan and other social services. There are also activities held by UIN Malang charity organization called "Elzawa" in collaboration with students, community, and public figures around Malang City. These activities are the implementation of the university's vision and mission and the UIN Malang curriculum in the form of the integrative religious practice and religious learning tradition.

Second, religious culture is reflected in rituals or practices and religious studies conducted in a calm and solemn atmosphere. It is realized in several activities; inviting kiai, habaib, leaders of Muslim community organizations either in regional, national, or international level to give religious speech as well as inviting majlis taklim and sholawat groups from East Java Province to read shalawat together. These activities are not only followed by university member (i.e. leaders, lecturers, staff, and students) but also opened for public. In these forums, all participants gain understanding on socio-religious values directly and other benefits. Another activity is holding activities which allow students and all university members to experience direct interaction across educational background and profession in UIN Malang. It can be realized by inviting communities from outside university. The campus can also conduct cross-study programs which are beneficial for not only lecturers and staff but also for students. Furthermore, in the context inside ma'had, kiai and murobby or murobbiyah as the ones advising every activity in the dorm must show exemplary behavior that can be the direct exposure for students to learn, especially in religious aspects implemented in daily life. Also, every routine activities followed by students can be the learning source; those are performing shalat jama'ah (congregational prayer) in mosque both at-Tarbiyah and Ulul Albab. Those aforementioned activities show that religious culture in UIN Malang has been going consistently well.

Third, IRP also depends on the competence of the lecturers and the kiai in ma'had council in carrying out the integrative learning tradition that guarantees social and religious understanding and religious power. To understand the religious and social-religious culture, the lecturers and the kiai deliver the integrative material flexibly and functionally that is appeared in three aspects; the first one, the course material presented by lecturers in the regular class of the department is related to religious and social values that 
take place in daily life on campus by looking at the function of integrating religious values; the next aspect, the religious material delivered by the kiai in $m a^{\prime} h a d$ is related to general science and the surrounding problems that are happening, by looking at the function of religious education in daily life; the last aspect, the behavior exposed by students, lecturers, staffs, and leaders in everyday communication and interaction influences the assessment of campus residents on the level of individual religious culture.

Fourth, the lecturers, the kiai in ma'had, and the students of UIN Malang take part in the implementation of the integration of college and ma'had life. They conduct discussion on certain issues in their respective faculty and dormitory. The continuation of activities will lead to the development of learning tradition socialization activities. Based on the aforementioned four aspects of IRP, religious culture in UIN Malang is then realized because of the existence and the consistency of holding numerous activities which integrate religious and scientific values.

\section{Determination of The Creation of Religious Culture}

The use of IRP as a potential of creating religious culture can be seen in the relationship between the learning tradition and the movement. The significance of the IRP on the level of religious culture influences student's behavior, attitudes, and integrative learning. To create religious atmosphere, religious culture allows every campus member to carry out religious services, rituals, and practices, as well as social studies in peace, calm, and solemn atmosphere. This aims at avoiding negative behavior and attitude which are not in line with social and religious norms. Also, this aims at realizing the profile of UIN Malang graduates i.e. moral grandeur, spiritual depth, breadth of knowledge, and professional maturity. Students and other member of UIN Malang (i.e. lecturers and staff) are accustomed to living together through academic and non-academic activities. In the academic aspect, they participate in religious and socio-cultural learning held by their respective majors/faculties and by ma'had. Non-academic wise, especially in social and religious activities, they in certain occasion hold social activities and religious rituals in each and across faculties as well as in collaboration with religious organizations outside campus with different educational and professional backgrounds. From these activities, they value the tolerance, peace, and solemnity in religious and cultural atmosphere.

Discussing about IRP signification in creating religious culture is inseparable from the presence of kiai, habaib, and leaders of Muslim organizations (e.g. majlis 
taklim and majlis sholawat) in regional, national, and international levels. They unite to not create any gap even though they may have different background in mazhab (schools). The process of religious activities can be described as; first, students get an understanding of the religious and social values taught by religious community leaders to produce polite, harmonious, religious and cultured behavior in addressing academic, socio-political, and religious issues on campus. Second, leaders of student organizations along with the students of UIN Malang are accustomed to helping each other. They usually target to help new students in ma'had to get used to campus life. They also help community leaders and religion worshipers from across regions and educational backgrounds to build openness, brotherhood, and not discriminating one another in a peaceful and solemn atmosphere. Third, the difference acceptance shown by religious figures in campus environment will teach students about tolerance and mutual respect. Fourth, there is brotherhood and comfort in religious and social activities carried out by students across faculties, regions, ethnicities, and countries. These four things reflect the significance of the IRP on the level of religious culture at UIN Malang.

The emergence of integrative learning in the era of globalization and information technology, learning materials and activities can be obtained through various integrated media and learning resources. In UIN Malang, cognitive, affective, and psychomotor integration aspects of religion and science are practiced in addition to face-to-face classrooms in respective faculty. They are also done in spaces in the community and through religious activities outside classroom. Ma'had uses intensive activities by incorporating religious values with the curriculum of each study program facilitated by the deans, the kiai council, and leaders of units within UIN Malang. The movement to create religious culture in UIN Malang uses the principle of flexibility and relevance as demonstrated by the practice of religious activities outside the classroom and the internalization of religious values according to events and moments. The data show that the ease in holding religious activities integrated with study programs and faculties encourages students and lecturers to improve the religious culture on campus.

\section{Religious Culture Model}

Integrative Religious Practice (IRP) is necessary as a reference to create religious culture that can be implemented as a solution of any problem in 
universities in Indonesia. Three things need to be fulfilled to develop the model that can be a solving for student and youth delinquency problems.

The first one is the principles of RC model. The IRP in UIN Malang was formulated using (1) the principle of flexibility as demonstrated by the willingness of advisors and supervisors in ma'had so that the taklim afkar activities and religious practices are in line with the mission of the institution; (2) the principle of openness shown by kiai and murobby-murobbiyah in ma'had to accept input from faculties in UIN Malang; (3) integrative principles as stated by Suhadak, chairman of Taklim Afkar in ma'had that one of functions of ma'had is to shape morality and spirituality of UIN Malang; and (4) the humanist principles demonstrated by the IRP is oriented to build a campus that is religious, peaceful, solemn, and equal through Khotmil Quran program followed by all campus residents and continued by eating together without differentiating the position and rank. The four principles encourage campus residents to work together, empathize, and to be civilized.

The second is construction model. UIN Malang uses IRP model made by (1) incorporating elements of religious values and character of Ulul Albab; (2) carrying out local wisdom activities to preserve an ancient religious ritual tradition that is still considered good and appropriate and not in contradiction with religious values; (3) integrating the rules in ma'had and faculty e.g. if there are students breaking the rules and acting crime in ma'had and outside the classroom, it will affect their assessment in the faculty. These three encourage campus citizens to behave in accordance with religious and social values.

The last one is the prerequisite model. UIN Malang compiles integrative religious practice and learning tradition shown by building an integrative facility, namely (1) establishing ma'had (students' dormitory) integrated with the campus; (2) building two mosques i.e. at-Tarbiyah and Ulul Albab. AtTarbiyah mosque is mostly used for male students since it is located near male dormitories, meanwhile Ulul Albab Mosque is intended for female students as it is located near female dormitories; (3) integrating religion and science studies as well as religious practices; and (4) lecture halls and meeting rooms in the campus can be used for taklim afkar, and religious activities carried out by ma'had. The data shows that the facilities and infrastructure that are built in an integrated manner can guarantee the realization of religious culture. This can be a reference for other universities in Indonesia. 


\section{Discussion}

Culture has significant relationship with maturity, behavior, and religious values, while religious beliefs encourage subjective norms and positive attitudes towards behavior (Aksoy \& Yusuf, 2019). The IRP and learning tradition implicitly expressed attitudes, knowledge, and behavior, which are indirectly communicated and shown through actions that are part of life in society (Jerald, 2006). Fimansyah, W. \& Kumalasari (2015) in their study reported that learning tradition that emphasizes rules, regulations, and routines could take the form of investment value, creating a conducive social climate, provision of physical facilities, or interaction patterns developed by educators. Cornbleth (1984) found that various elements have an impact on shaping religious cultures, such as teachers, students, society, knowledge, and awareness. In the context of UIN Malang, religious practices are integrated inside and outside the classroom (in this paper referred to as IRP). The implementation of the IRP in the regular class is in formal way led by each lecturer, while the IRP held outside the class is in the form of ceremonial such as in ma'had, mosques, and outside the campus. The implementation of the IRP outside the classroom involved student leaders in each faculty, every dormitory (mabna) in ma'had, takmir (staff) of the campus mosque, and in Haiah Tahfiz al-Quran (an organization in charge of managing students in memorizing Quran).

The involvement of all leaders in each element inside and outside campus leads to at least two new consciousness. First, their existence can provide comparative perspectives and diversity to enrich students' insight and campus leaders to build togetherness and create Religious Culture (RC). Second, the experience gives new values and reference in communicating with various parties and forming a peaceful, solemn, fraternal, and religious environment. In this way, students and other members in the campus will gain a wealth of experience that enables each of them to be more open toward different belief and ethnic leading to the creation of RC. According to Vygotsky (in Alsubaie, 2015), the development of higher psychological processes can arise through implicit or hidden messages. Vygotsky suggests that lecturers improve and contribute to help and encourage students to communicate socially. This process is called the presupposition of values and moral commitment. When lecturers realize the importance of IRP and learning tradition on students, they will apply it using collaborative strategy.

el Harakah Jurnal Budaya Islam Vol. 22 No. 1 Tahun 2020 
IRP is a medium and a mean of expressing and representing the attitude, knowledge, and behavior, delivered indirectly through the implementation of educational activities and religious practices by integrating religion and science as well as take advantage of various relevant elements to achieve institution's vision, mission, and goals. In the implementation of IRP in UIN Malang, religious practice material is reviewed by using an interdisciplinary framework and is developed by linking the problems that occur and rise in daily life. The material was delivered in the regular class, in the ma'had class, in the mosque, and outside the classroom as well as through modeling, exemplary, and religious symbols in writing and signs in the stone monument. While the strategies used include tutorials, lectures, religious ritual practices, and habituation. The activity is intended so that students and the academic community can understand the relevance of religion, science, and problems in the campus environment. These activities also gained the benefits and experience of learning to build a religious culture to foster religious attitudes and behavior for students and campus residents as the implementation of religious values in daily life.

The creation of religious culture is an effort that allows every campus citizen to apply religious values that are trusted and believed in good, innovative, and creative ways in a peaceful, calm, and solemn atmosphere. This activity will create religious atmosphere that is considered correct and conditional. Muhaimin et al. (2001, p.306 -307) classify four models of religious culture i.e. structural, formal, mechanical, and organic. In the context of UIN Malang, models that are practiced include structural models built through regulation and building public image both from the internal and external environment realized through monthly Khotmil Quran. Moreover, there are also other activities such as the socioreligious-theme speech (kultum i.e. seven-minute speech) after dhuhur prayer in the mosque delivered by lecturers of UIN Malang and figures outside campus (set in a schedule) and several religious rituals led by kiai and the murobbi-murobbyah (kiai's assistants) in UIN Malang. The mechanical and organic models are demonstrated through the functioning of existing units such as Haiah Tahfiz al-Quran fostering students from various majors who are interested in memorizing Quran and doing tahsin (checking and revising the Quran reading), the center for studying science integration that examines and gives consideration in positioning Quran and hadith as primary sources related to human's daily life and behavior. They can be learned in the classroom, in the office, and outside the classroom. 
The involvement of all campus elements in the creation of RC following their respective authorities will create and maintain religious environment. They will feel uncomfortable to witness misbehavior in their surrounding environment since it will make negative atmosphere. In this way, the campus community will gain experience of religious behavior and be accustomed to not acting negatively. Religious and self-regulated culture have positive influence on students' religious behavior (Pratama et al. 2019). Thus, the application of religious values will be realized through integrative religious practice as a tradition and become a religious culture in the campus environment.

\section{Conclusion}

It turned out that the religious culture on campus can be built by integrative religious practice (IRP) by inserting religious values, local wisdom, as well as implementing the rules which have been agreed upon. This condition can foster a comfortable, peaceful, and religious atmosphere. The IRP is integrated through teaching and learning activities. Involving various elements of religious organizations and community leaders outside the campus can increase brotherhood, togetherness, and insight in building and maintaining religious atmosphere in the college. This also emphasizes the need for the religious culture through the development of the IRP to get out of the narrow space of the textual curriculum, which closes the space for interaction based on diversity and religious values.

This research is limited to the analysis of religious culture through IRP, which is practiced in UIN Maulana Malik Ibrahim Malang so that it has not been able to reach an explanation of whether the religious culture does not contribute to the formation of a culture of radicalism. In other words, the potential of Pancasila (Indonesian five-basic principles) education and religion courses in tertiary institutions develops a comfortable, peaceful, and religious culture. The analysis of the learning tradition in higher education-by looking at how each course can encourage the creation of religious values, togetherness, brotherhood, and tolerance-becomes important in looking at the position of higher education in reproducing freedom of opinion and behavior by considering religious values to power base religious culture.

\section{Reference}

Aksoy, H., \& Yusuf A. O. 2019. Exploring the impact of religiousness and culture on luxury fashion goods purchasing intention A behavioral 
study on Nigerian Muslim consumers. Journal of Islamic Marketing, 10 (3), 768-789. https://doi.org/10.1108/JIMA-01-2018-0022

Ali, N., Miftahusyai' an, M., Prasetyo, A.T., \& Muttaqin, I. M. 2018. Implementasi kurikulum integratif UIN pada ma'had mahasiswa UIN Maulana Malik Ibrahim Malang. LP2M UIN Malang

Ali, N. 2019. The integrative curriculum of religion and science at special pesantren for university students. Ulul Albab Jurnal Studi Islam, 20 (1), 95-122. https://doi.org/10.18860/ua.v20i1.6353

Alsubaie, M. A. 2015. Hidden curriculum as one of the current issues of curriculum. Journal of Education and Practice, 6(33), 125-128. Retrieved from www.iiste.org\%0Awww.iiste.org

Andrianto, A. 2019. Faktor-faktor penyebab kenakalan remaja di Lebab mulyo kecamatan Kemuning Kota Palembang. Jurnal PAI Raden Fatah, 1(1), 82-104.

Ariyanik, S., \& Suhartini, E. 2012. Fenomena kenakalan remaja di desa Wonorejo kabupaten Situbondo. Jurnal Entitas Sosiologi, I(2), 16-26.

Cornbleth, C. 1984. Beyond hidden curriculum? Journal of Curriculum Studies, 16 (1), 29-36. https: //doi.org/10.1080/0022027840160105

Fimansyah, W \& Kumalasari, D. 2015. Penanaman nilai-nilai nasionalisme melalui pembelajaran sejarah di SMA Kebangsaan Yogjakarta. Prosiding Penelitian Dan Pengabdian Kepada Masyarakat, 10(2), 87-102. https : // doi.org/10.24198/ jppm.v4i2. 14393

Fitri, A.Z., Nafis, M.M., Mujib, F. 2019. Integration of walisongo's da'wah with science in Indonesian national qualification framework. El Harakah, 21(1), 37-64.

Ghony, M. D. 2018. Agama dan Kekerasan Massa. El Harakah (Terakreditasi), 4(3), 11-17.

Hamidah, L. N. 2016. Strategi internalisasi nilai-nilai religius siswa melalui program kegiatan keagamaan: Studi multi kasus di SMAN I Malang dan MAN 1 Malang. (UIN Maliki Malang). http: //etheses.uin-malang.ac.id /4083/1/14770011.pdf 
Irsad, M. 2016. Pengembangan kurikulum pendidikan agama Islam di madrasah: Studi atas pemikiran Muhaimain. Iqra', 2(1), 230-268.

Jerald, C. D. 2006. School culture: "the hidden curriculum (Vol. 331). www. centerforcsri.org

Kameliah, N. 2017. Tinjauan kriminologi konflik mahasiswa dalam kampus: Studi kasus tawuran mahasiswa UIN Alauddin Makassar). Makasar.

Khuzaimah. 2017. Paradigma pengembangan kurikulum pendidikan agama Islam di sekolah (Analisis berbagai kritik terhadap PAI). Jurnal Kependidikan, 5(1), 81-90.

Logan, K. R., \& Hartwick, J. M. M. 2019. Teaching and talking about religion: strategies for teacher educators. Social Studies Research and Practice, 14(2), 167-179. https: //doi.org/10.1108/ssrp-05-2019-0027

Maulana, D. H. 2019. Cekcok masalah spanduk, 2 kelompok mahasiswa USU saling serang. https://news.detik.com/berita/d-4806794

Muhaimin, Suti'ah, \& Ali, N. 2001. Paradigma Pendidikan Islam Humanis (1st ed.). Bandung: Remaja Rosdakarya.

Pratama, S., Siraj, A., \& Yusuf T, M. 2019. Pengaruh budaya religius dan self regulated terhadap prilaku keagamaan siswa. Edukasi Islami :Jurnal Pendidikan Islam, 8(2), 331-346.

Ramadhan, B. 2017. Tawuran mahasiswa universitas Riau coreng dunia pendidikan. Republica.com website: https: //nasional.republika.co.id /berita/nasional/daerah/17/10/06

Reinhard. 2019. Tawuran mahasiswa saat sahur terjadi lagi di Makassar News detik.com website: https://news.detik.com/berita/d-4566081

Setiyawati, R. 2015. aktualisasi nilai-nilai islam-dalam kehidupan kampus. https: //beritalangitan.com/news

Sulis, H. 2018. Tawuran mahasiswa UIN Alauddin Makassar. https: //lampung. tribunnews.com/2018/10/23/ tawuran mahasiswa uin alauddin makassar

Suyitno. 2018. Strategi pembentukan budaya religius untuk meningkatkan karakter islami di sekolah dasar Muhammadiyah Wirobrajan 3 Yogyakarta. Edukasi: Jurnal Pendidikan, 10(2), 191-204.

el Harakah Jurnal Budaya Islam Vol. 22 No. 1 Tahun 2020 
Syaifuddin, A. 2018. Internalisasi Pendidikan Agama Islam Melalui Budaya Religius dalam Menanggulangi Penyalahgunaan Narkoba di MAN Tuban Tahun Pelajaran 2015-2016. 14, 1-9. http: //www.bkkbn.go.id/ViewBerita. aspx?BeritaID $=2444$

Syifaunnufush, A. D., \& Diana, R. R. 2017. Kecenderungan kenakalan remaja ditinjau dari kekuatan karakter dan persepsi komunikasi empatik orangtua. Jurnal Psikologi Integratif, 5(1), 47-68.

Zamzami, M. C. 2015. Penguatan pengalaman keagamaan di sekolah. J-PAI: Jurnal Pendidikan Agama Islam, 1(2), 293-310. https: //doi.org/10.18860/ JPAI.V1I2.3353 